\title{
Exploring stream of consciousness as a narrative technique in modern novels
}

\begin{abstract}
This paper provides various discussions and opinions on stream of consciousness in general and how it has flourished from its origins until modern times and its appearance in modern novels. The present paper includes several parts: stream of consciousness according to critics, how the concept has flourished in the history of the modern novel and its sources, including the novelists who developed it. In addition, psychoanalytical discussion is considered according to the Freudian theory of dream work and its relation to this research. The main aim in this paper is to make readers understand the modern concept of stream of consciousness in the context of modern novels and its psychological consequences according to Freudian psychological theory. In discussions of stream of consciousness, Joyceâs contributions should be emphasized because he developed the technique (Steinberg 7). Joyce and his brother, Sianislaus, worked on a type of writing employing stream of consciousness. This paper also touches on some other authors connected lo stream of consciousness, such as Woolf and Richardson, and briefly discusses their impact on the literary world.
\end{abstract}

Keyword: Stream of consciousness; Psychoanalysis; Interior monologue; Memory; Literary technique 